\title{
Rickets and Osteomalacia in the Glasgow Pakistani Community, I96I-7I
}

\author{
J. A. FORD, E. M. COLHOUN, W. B. McINTOSH, M. G. DUNNIGAN
}

British Medical fournal, 1972, 2, 677-680

\section{Summary}

The prevalence of vitamin $D$ deficiency was reassessed in April and May 1971, 10 years after the discovery of widespread late rickets and osteomalacia in the Glasgow Pakistani community. Evidence of vitamin $D$ deficiency was found in 28 out of 115 adults and children examined (24\%). Children at the age of puberty were most severely affected by rickets, whereas most infants and younger children in the survey were protected by vitamin $D$ supplements. Mild biochemical osteomalacia was common in Pakistani women.

A total of 21 Pakistani and Indian children with rickets were admitted to Glasgow hospitals during 1968-70. These comprised 10 children with infantile rickets and 11 with late rickets. Four of the latter group required osteotomy for severe rachitic deformity.

Late rickets and osteomalacia in Pakistani and Indian immigrants are not primarily due to nutritional deficiency of vitamin $D$, though the high phytate content of their diet may be of aetiological importance. A combination of environmental, social, and endogenous factors, the relative importance of which is not at present clear, may also be involved. Advice on the prophylaxis of vitamin D deficiency should be given to all Pakistani and Indian communities in the United Kingdom.

\section{Introduction}

Late rickets and osteomalacia were first found in Pakistani children and adults living in Glasgow in 1961 (Dunnigan et al., 1962). Children at the age of puberty were most severely affected and several required osteotomy for rachitic deformity. Benson et al. (1963) and Arneil and Crosbie (1963) subsequently described infantile rickets in immigrant children living in London and Glasgow respectively, while Felton and Stone (1966) and Swan and Cook (1971) reported late rickets and osteomalacia in Pakistani and Indian patients in Birmingham.

The present study examined the prevalence of vitamin D deficiency in the Glasgow Pakistani community a decade after the original investigation and was stimulated by reports of continuing hospital admissions of older Pakistani and Indian children with severe rickets. It comprised an examination of 26 Pakistani families for evidence of vitamin D deficiency and a survey of admissions of Pakistani and Indian children with rickets to all Glasgow hospitals in the years 1968-70.

\section{Subjects and Methods}

Survey of Pakistani Families.-A form explaining the purpose of the survey was distributed by the president of the Glasgow Pakistani Social and Cultural Society to each of 50 households. He was unfamiliar with the medical background of the households and the survey was therefore not biased towards the

Stobhill General Hospital, Glasgow N.1

J. A. FORD, M.B., CH.B., M.R.C.P., Senior Registrar in Paediatrics

E. M. COLHOUN, S.R.N., S.C.M., Ward Sister

W. B. MCINTOSH, A.I.M.L.T., Senior Technician

M. G. DUNNIGAN, M.D., F.R.C.P., Consultant Physician selection of families including subjects with symptoms suggestive of vitamin D deficiency. Twenty-six $(52 \%)$ of the families agreed to participate. These families, comprising 116 persons, were examined during April and May 1971. They ranged from the families of business men to those of artisans and unskilled labourers. Families were visited at home when note was taken of possible relevant symptoms and of the consumption of vitamin D supplements. A non-fasting blood sample was taken from each member for estimation of serum calcium, inorganic phosphorus, and alkaline phosphatase. Each person with abnormal biochemical findings was re-examined in Stobhill Hospital, where a confirmatory blood sample was taken for biochemistry and routine haematology. The knees and wrists of children with biochemical rickets were radiographed and a dietary history was taken from 10 rachitic children. Four children with severe rickets were admitted for additional investigations to exclude malabsorption and renal disease. These comprised urinary calcium excretion, serum urea and electrolytes, xylose absorption, faecal fat excretion, and barium meal and follow-through examination. Jejunal biopsy was performed on two children.

Laboratory Investigations. - Blood samples taken at home were centrifuged soon after withdrawal and the sera deep frozen until needed. Serum calcium, inorganic phosphorus, and alkaline phosphatase were determined on a Technicon AutoAnalyzer in the biochemistry department of Stobhill Hospital. In this laboratory a study of serum calcium levels in 200 hospital patients without obvious metabolic disease gave a range of $8 \cdot 3-10 \cdot 8 \mathrm{mg} / 100 \mathrm{ml}$ ( $95 \%$ confidence limits). It seems probable that the lower limit of this range included patients with minor degrees of hypocalcaemia. In the present study, however, only values of serum calcium below $8.3 \mathrm{mg} / 100 \mathrm{ml}$ were considered definitely abnormal. Normal values for serum inorganic phosphorus, which vary with age and sex, were derived from the data of Greenberg et al. (1960). Values of serum alkaline phosphatase above $15 \mathrm{King}$-Armstrong units $/ 100 \mathrm{ml}$ for adults and $30 \mathrm{~K}$.A. units $/ 100 \mathrm{ml}$ for children were regarded as abnormal. The latter value slightly exceeds the upper limit of normal accepted by most authors (Gray, 1965; Nordin and Smith, 1965; Richards et al., 1968a).

Hospital Admissions with Rickets. - Information on admissions to all Glasgow hospitals with the diagnosis of rickets (I.C.D. 265) was obtained from the Scottish Home and Health Department for the years 1968-70 inclusive. Pakistani and Indian children were identified by name and their case records subsequently examined.

Classification of Vitamin D Deficiency.-As before (Dunnigan et al., 1962), adults and children with evidence of vitamin D deficiency were divided into four groups according to severity; the classification was adapted from that used by Albright $e t$ al. (1946) for osteomalacia: (1) serum calcium and/or inorganic phosphorus low, alkaline phosphatase normal; (2) serum alkaline phosphatase raised \pm 1 ; (3) radiological and biochemical evidence of rickets or osteomalacia; and (4) radiological, biochemical, and objective clinical evidence of rickets and osteomalacia (bone deformity).

\section{Results}

\section{SURVEY OF PAKISTANI FAMILIES}

In the 26 families surveyed, comprising 115 persons, 28 adults and children ( $24 \%$ ) showed evidence suggestive of vitamin D 
Biochemical, Radiological, and Clinical Evidence of Vitamin Deficiency in 26 Pakistani Families (116 Persons)

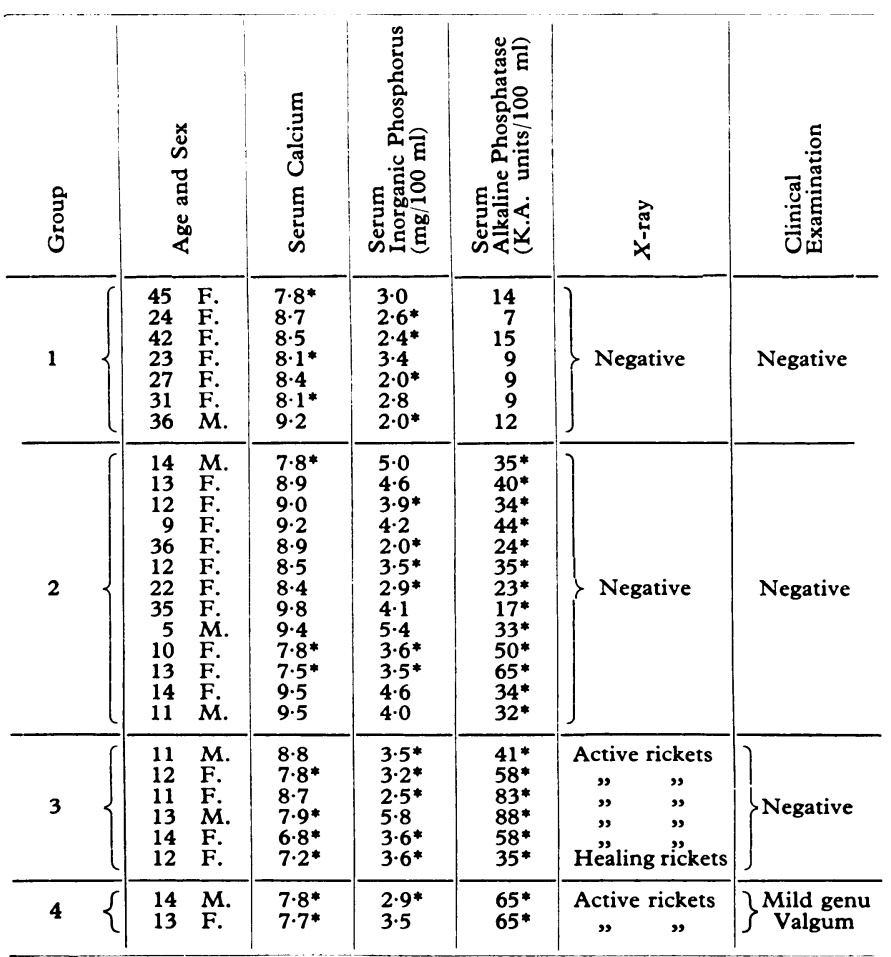

* Abnormal value.

deficiency (see Table). Twenty showed only biochemical evidence of rickets or osteomalacia (groups 1 and 2). Six children also showed radiological evidence of rickets (group 3 ) and two showed mild genu valgum (group 4). There was a marked female preponderance in the prevalence of vitamin D deficiency in both adults (nine women, one man) and children (12 girls, six boys). A feature of the present survey, noted in the previous one, was the familial occurrence of vitamin $\mathrm{D}$ deficiency. Two families each contributed two members with vitamin D deficiency, one family three members, and one no fewer than six.

All the severe cases of rickets in groups 3 and 4 occurred in children around the age of puberty (see Fig. B). In the age group 9-16 years, 5 out of 11 males $(45 \%)$ and 12 out of 18 females $(66 \%)$ showed clear biochemical evidence of rickets. Of 42 children under 9 years, only one, a boy aged 5 , showed a slightly raised alkaline phosphatase level (see Fig. A). Of the older adolescents and adults examined, 9 out of 30 women $(30 \%)$ and 1 out of 14 men showed mild biochemical osteomalacia (see Fig. C).

Infants and children under the age of puberty thus emerged, paradoxically, as the age group with the least evidence of vitamin $\mathrm{D}$ deficiency. This seemed to be due to the high proportion of preschool children in the sample who were receiving vitamin $\mathrm{D}$ supplements, obtained from child welfare clinics (18 out of 21 ; $85 \%$ ). Eleven out of 21 children $(52 \%)$ aged $5-8$ years were also taking vitamin D supplements, but only 7 out of 28 children $(25 \%)$ aged 9-16 years were protected. No adult was taking additional vitamin $\mathrm{D}$.

All the rachitic children in groups 3 and 4 complained of pains in the legs, usually localized to the knees and aggravated by exercise. In some cases the pains were severe and had prevented the children running or playing games. A number of pubertal children in group 2 with biochemical evidence of rickets only also complained of limb pains of varying severity. No adult with biochemical osteomalacia was symptomatic, except for one woman with low back pain of doubtful significance.

As in the original study, all the rachitic children examined seemed to be sturdy and well nourished, and all fell within the normal range of height and weight for their stated ages. None was anaemic. The estimated vitamin $D$ intakes of 10 rachitic children ranged from 129-243 IU of vitamin D daily with a mean intake of 189 IU daily. These intakes are similar to recent estimates of the vitamin D intakes of white children and adults in the United Kingdom (Panel on Child Nutrition, 1970; Hunter et al., 1971; Lumb et al., 1971).

None of the four children admitted for inpatient investigation showed evidence of malabsorption or renal disease, apart from the amino-aciduria common in vitamin D deficiency (Jonxis et al., 1952). The jejunal biopsies performed on two children were normal.

All the children and most of the adults with evidence of vitamin D deficiency in groups $1-4$ were treated with 3,000 IU of calciferol daily together with calcium supplements. All showed a prompt biochemical response to this therapy. At the end of three months' treatment they were biochemically normal and (in the case of groups 3 and 4) showed complete radiological healing. Children with limb pain were asymptomatic.

\section{SURVEY OF HOSPITAL ADMISSIONS WITH RICKETS}

In the three-year period 1968-70 14 Pakistani and seven Indian children were admitted to Glasgow hospitals with confirmed

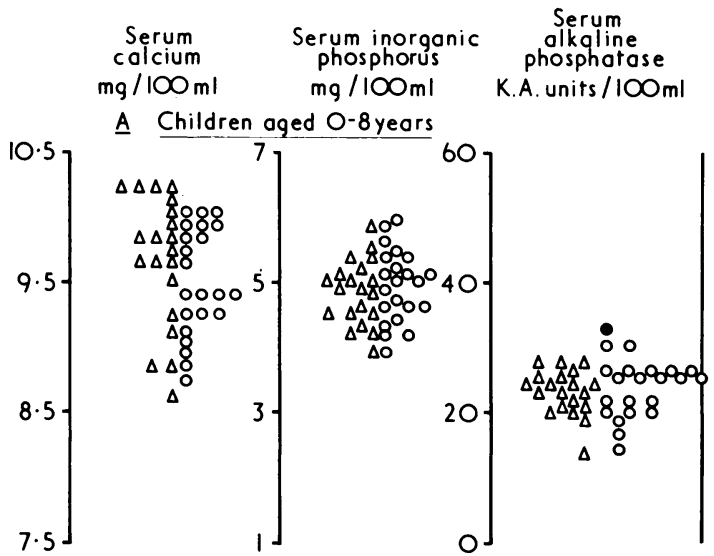

B Children aged $9-16$ years
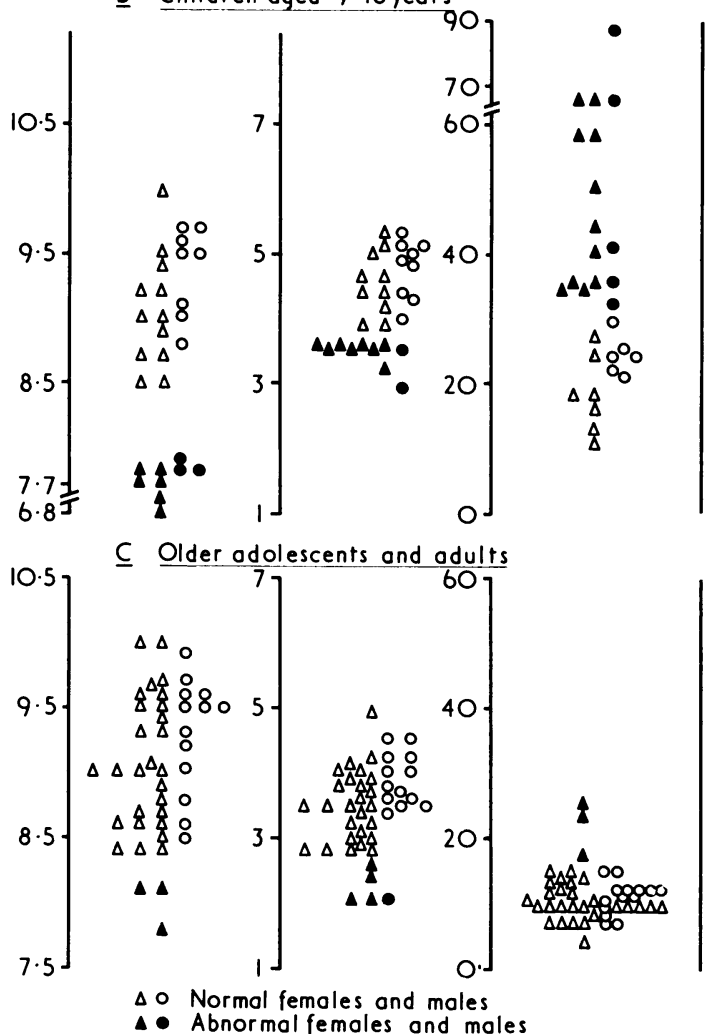

FIG. 1-Pakistani family survey: serum calcium, inorganic phosphorus, and alkaline phosphatase levels in (A) children aged 0-8 years, (B) children aged 9-16 years, and $(C)$ older adolescents $(>16$ years) and adults. 
rickets. Ten of these were infants under 2 years. The remaining 11 were aged 6 to 15 years. Of the older children with rickets, two were in group 2 , two in group 3 , and seven in group 4 with rachitic deformity. Four of the children with late rickets have had osteotomies performed for severe deformity, with prolonged periods in hospital and a fifth child required osteotomy.

\section{Discussion}

The Glasgow Pakistani community, numbering some 5,000 persons, has been established for over 20 years. Most of the children examined were born in the city, and all had lived in it for at least five years, except for one boy aged 14 with rickets, who had moved three weeks previously from Huddersfield. A feature of the community is the industry and devotion to self-improvement of its members, characteristic of many first-generation immigrant communities, and a marked concern for the welfare of its children. This is illustrated by the high uptake of welfare foods for preschool children. Modest prosperity characterized most of the households visited in the present survey and none showed poverty or deprivation.

Despite this, the present survey has repeated the findings of a decade earlier by demonstrating that vitamin $\mathrm{D}$ deficiency is still common among Pakistanis living in Glasgow. The study of hospital admissions has shown that the smaller Indian community seems similarly involved. Children at the age of puberty are most severely affected, many complaining of limb pains, and a minority progressing to severe rachitic deformity requiring surgical correction. The female adult community shows evidence of mild biochemical osteomalacia while preschool children are largely protected by vitamin $\mathrm{D}$ supplements.

The causes of the late rickets and osteomalacia seen in the present survey, and in the previous one, differ from those of infantile rickets in immigrant and white children in the United Kingdom. Infantile rickets is usually due to feeding with pasteurized cows' milk, with its low vitamin $\mathrm{D}$ content, to prolonged breast-feeding or to lack of administration of vitamin D supplements. The children usually exhibit iron-deficiency anaemia and come from families of poor socioeconomic status (Richards et al., 1968b; Stroud, 1971). The term "nutritional" is appropriate to rickets of this kind. The present study did not reveal any cases of infantile rickets, possibly because poorer and less socially aware families are unlikely to take part in a voluntary survey. Infantile rickets does occur in Pakistani and Indian children in Glasgow. It constituted 10 of the 21 admissions of immigrant children with rickets to Glasgow hospitals during 1968-70. Scrutiny of the case records showed that the operative factors were those described above, and all the infants were iron-deficient.

Dunnigan and Smith (1965) carried out a detailed study of the dietary patterns of rachitic and non-rachitic Pakistani schoolchildren and of a control group of non-rachitic white children living in the same area of Glasgow. The food intake of each child who participated was weighed and recorded over a seven-day period. No significant differences emerged between the white and immigrant groups in terms of vitamin D, mineral, or caloric intakes but the diets of the Pakistani children were significantly higher in phytic acid due to their consumption of chupattis. The recorded vitamin $\mathrm{D}$ intakes were similar to those of two previous individual surveys (Widdowson, 1947; Bransby and Fothergill, 1954). The estimated vitamin D intakes of rachitic Pakistani children in the present survey are of the same order as those recorded previously and, as noted above, are similar to more recent estimates of the intakes of British white children and adults. Because their vitamin D intakes do not differ materially from those of their white counterparts, nutritional deficiency of vitamin $D$ does not seem to be a factor in the aetiology of late rickets and osteomalacia in Pakistani immigrants. It may be noted that none of the children with late rickets seen in the present survey, or the previous one, was anaemic, in contrast to the almost universal occurrence of iron-deficiency anaemia in infantile rickets.

Dunnigan and Smith (1965) did not consider the high phytate content of the Pakistani diet, noted above, to be important in the genesis of late rickets and osteomalacia, and the role of phytate in this regard has been controversial. Wills et al. (1972) suggested that phytate in unleavened flour may be responsible for late rickets and osteomalacia in Indian and Pakistani immigrants and reported a case of late rickets in an Indian adolescent which responded to reduction in the phytate content of his diet without alteration in its vitamin $\mathrm{D}$ content. This hypothesis clearly merits careful study and further experimental verification.

The relative importance of the non-nutritional, environmental, social, and endogenous factors involved in the high prevalence of vitamin $\mathrm{D}$ deficiency in the Glasgow Pakistani community remain unclear. Several of the possible contributory causes seem less plausible than when first considered 10 years ago. Glasgow, with its northern latitude, high tenements, and atmospheric pollution (which is much less now than a decade ago) provides an environment in which rickets still occurs in white infants who do not receive supplementary vitamin D. Despite this, simple vitamin-D-deficiency rickets is not seen in the indigenous population outside infancy (G. C. Arneil, personal communication, 1964). A study of serum alkaline phosphatase levels in apparently healthy white schoolchildren living in central Glasgow showed only two children with slight rises over $30 \mathrm{~K}$.A. units/100 ml (Dunnigan and Gardner, 1965). Domicile in Glasgow is therefore not sufficient per se to explain the proneness of members of the Pakistani community to develop late rickets and osteomalacia.

The female preponderance of vitamin $\mathrm{D}$ deficiency in the Pakistani community has been thought to reflect the greater tendency of women and girls to remain housebound than their male counterparts, thereby reducing exposure to ultraviolet irradiation. Despite this, detailed inquiry from several girls with pubertal rickets showed that they walk to and from school, take part in outdoor games and recreation at school, and visit near-by parks at the week-ends, usually in family groups.

Skin pigmentation is a further possible aetiological factor by reducing the irradiation of 7-dehydrocholesterol by ultraviolet light and thereby its conversion to cholecalciferol (vitamin $\mathrm{D}_{3}$ ) (Loomis, 1967). It should be noted, however, that Pakistanis living in Glasgow are almost all Punjabis whose skins are no darker than those of many Southern Europeans.

A possible endogenous factor is suggested by the familial distribution of vitamin $\mathrm{D}$ deficiency found in this study and in the previous one. Multiple cases occur in families whose dietary intakes of vitamin $\mathrm{D}$ and mode of life do not obviously differ from families without evidence of deficiency. This may reflect genetic differences in ability to synthesize cholecalciferol or to convert it to its more active metabolites in the liver and kidney.

Regardless of aetiology, pubertal rickets in Pakistani and Indian children is still a poorly recognized clinical entity. Many cases are treated with simple analgesics or regarded as having minor orthopaedic complaints unless deformity appears. That four osteotomies should be necessary in three years for severe rachitic deformity (and a fifth is required) is testimony to this. In our view any Pakistani or Indian child who complains of limb pains should be regarded as having rickets until proved otherwise. The demonstration of one case of rickets in a family should lead to the screening of its remaining members. Vitamin D deficiency is almost certainly still present in other Pakistani and Indian communities in the United Kingdom; as noted previously, one of our patients had just moved from Huddersfield.

The demonstration of continuing widespread vitamin D deficiency in the Glasgow Pakistani community represents a failure of preventive medicine. All Pakistani and Indian children in Glasgow (and probably in the United Kingdom) should receive vitamin $\mathrm{D}$ supplements until at least 16 years of age. Pakistani women would also benefit from vitamin $D$ supplements. Education of the members of Pakistani and Indian communities 
in the need for these prophylactic measures is urgently necessary and overdue.

We are grateful to Dr. S. Haase for radiological assistance, and to the Dietetic Department, Stobhill Hospital, for help with the diet histories. We are also indebted to Mr. F. M. Sharif, President of the Glasgow Pakistani Social and Cultural Society, through whom the survey was arranged, and to the families themselves for their willing participation. Professor J. H. Hutchison, Royal Hospital for Sick Children, Glasgow, and Mr. A. McDougall, Victoria Infirmary, Glasgow, kindly allowed us access to the case records of rachitic patients under their care.

\section{References}

Albright, F., Burnett, C. H., Parson, W., Reifenstein, E. C., and Roos, A. (1946). Medicine, 25, 399.

Arneil, G. C., and Crosbie, J. C. (1963). Lancet, 2, 423.

Benson, P. F., Stroud, C. E., Mitchell, N. J., and Nicolaides, A. (1963).

British Medical fournal, i, 1054.

Bransby, E. R., and Fothergill, J. E. (1954). British fournal of Nutrition, 8 ,
Dunnigan, M. G., et al. (1962). Scottish Medical Fournal, 7, 159.

Dunnigan, M. G., and Gardner, M. D. (1965). Scottish Medical fournal, 10, 325.

Dunnigan, M. G., and Smith, C. M. (1965). Scottish Medical fournal, 10,1. Felton, D. J. C., and Stone, W. D. (1966). British Medical Fournal, 1, 1521. Gray, C. H. (1965). Clinical Chemical Pathology, London, Arnold.

Greenberg, B. G., Winters, R. W., and Graham, J. B. (1960). fournal of Clinical Endocrinology and Metabolism, 20, 364.

Hunter, J., Maxwell, J. D., Stewart, J. D., Parsons, V., and Williams R. (1971). British Medical fournal, 4, 202.

Jonxis, J. H. P., Smith, P. A., and Huisman, T. H. J. (1952). Lancet, 2,

Loomis, W. F. (1967). Science, 157, 501.

Lumb, G. A., Mawer, E. B., and Stanbury, S. W. (1971). American fournal of Medicine, 50, 421.

Nordin, B. E. C., and Smith, D. A. (1965). Diagnostic Procedures in Disorders of Calcium Metabolism. London, Churchill.

Panel on Child Nutrition (1970). Reports on Public Health and Medical Subjects, No. 123. London, H.M.S.O.

Richards, I. D. G., et al. (1968a). Scottish Medical Fournal, 13, 297.

Richards, I. D. G., Sweet, E. M., and Arneil, G. C. (1968b). Lancet, 1, 803. Stroud, C. E. (1971). British fournal of Hospital Medicine, 5, 629.

Swan, C. H. J., and Cooke, W. T. (1971). Lancet, 2, 456.

Widdowson, E. M. (1947). Medical Research Council, Special Report Series. No. 257. London, H.M.S.O. Wills, M. R., Day, R. C., Phillips, J. B., and Bateman, E. C. (1972). Lancet,

\section{Follow-up of Cases of Opiate Addiction from the Time of Notification to the Home Office}

\section{Introduction}

A total of 108 cases of opiate* addiction were followed up for six to seven years until April 1971. The five-year follow-up from first contact with us was published elsewhere (Chapple et al., 1972), together with a method of staging according to the time since notification to the Home Office when first seen. Stage 1 or "early" addicts were defined as those seen within three months of initial notification, stage 2 or "pre-chronic" addicts three to 18 months, and stage 3 or "chronic" addicts those notified more than 18 months previously. The number of opiate-free patients after five years was shown to be significantly different for addicts at the three stages.

*Opiates for the purposes of this study include heroin, pethidine, morphine, methadone. Nevertheless, all but one of the 108 were using heroin when first seen by us.

National Addiction and Research Institute, London S.W.10

PETER A. L. CHAPPLE, M.B., D.P.M., Medical Director

DAVID E. SOMEKH, M.B., CH.B., Research Unit

MARILYN E. TAYLOR, B.A., Research Unit

\section{Patients}

All the patients were first seen by one of us (P.A.L.C.) between November 1963 and September 1965 inclusive. Twelve were seen at St. Giles' outpatient clinic, 31 at Lambeth outpatient clinic, 28 at Cane Hill Hospital (mostly as outpatients, a few as inpatients), 32 at West Park Hospital (similarly), and 5 as general practice patients. They later dispersed to several treatment situations. Some who remained with us were referred back to their general practitioner after discharge from hospital and jointly supervised either at the outpatient clinic or later at the National Addiction and Research Institute in Chelsea.

The status of each patient in April each year after their first contact with us was ascertained primarily from the Home Office

TABLE I-Age, Sex, and Country of Origin of Present Patients and of All New Patients in Great Britain during 1955-64. All Patients were Non-therapeutic Addicts

\begin{tabular}{|c|c|c|c|c|c|}
\hline & & \multirow{2}{*}{$\begin{array}{c}1955-64 \\
\text { Sample } \\
(\%)\end{array}$} & \multirow{2}{*}{$\begin{array}{c}\text { Present } \\
\text { Patients } \\
(\%)\end{array}$} & \multicolumn{2}{|c|}{ Mean Age in Years } \\
\hline & & & & $\begin{array}{l}\text { 1955-64 } \\
\text { Sample }\end{array}$ & $\begin{array}{l}\text { Present } \\
\text { Patients }\end{array}$ \\
\hline $\begin{array}{l}\text { British origin } \\
\text { Non-British origin }\end{array}$ & $\begin{cases}\text { Men } & \cdots \\
\text { Women } & \cdots \\
\text { Men } & \cdots \\
\text { Women } & \cdots\end{cases}$ & $\begin{array}{r}54 \\
23 \\
20 \\
3\end{array}$ & $\begin{array}{r}61 \cdot 0 \\
24 \cdot 5 \\
12 \cdot 5 \\
2 \cdot 0\end{array}$ & $\begin{array}{l}24 \cdot 6 \\
21 \cdot 8 \\
31 \cdot 4 \\
30 \cdot 2\end{array}$ & $\begin{array}{l}23 \cdot 7 \\
21 \cdot 7 \\
31 \cdot 6 \\
32 \cdot 5\end{array}$ \\
\hline Total & $\left\{\begin{array}{l}\text { Men } \\
\text { Women }\end{array}\right.$ & $\begin{array}{l}74 \\
26\end{array}$ & $\begin{array}{l}73 \cdot 5 \\
26 \cdot 5\end{array}$ & $\begin{array}{l}26 \cdot 4 \\
22 \cdot 3\end{array}$ & $\begin{array}{l}24 \cdot 5 \\
22.5 \\
\end{array}$ \\
\hline No. of patients $\ldots$ & . & 436 & $105^{*}$ & & \\
\hline
\end{tabular}

*Three patients registered before 1955 are excluded.

TABLE II-Age of Sample compared with All Heroin Users in 1964 and 1965 in Great Britain. Figures given are Percentages

\begin{tabular}{|c|c|c|c|c|c|c|}
\hline \multicolumn{4}{|c|}{ Age (years) } & \multirow{2}{*}{$\begin{array}{l}1964 \\
12.5 \\
68.5 \\
19 \cdot 0\end{array}$} & \multirow{2}{*}{$\begin{array}{c}108 \text { Cases } \\
21 \cdot 5 \\
66 \cdot 5 \\
12 \cdot 0\end{array}$} & \multirow{2}{*}{$\begin{array}{l}1965 \\
26.5 \\
63.0 \\
10.5\end{array}$} \\
\hline $\begin{array}{ll}\text { Under } & 20 \\
20-34 & \ldots \\
35-49 & \ldots\end{array}$ & $\begin{array}{l}\cdots \\
\cdots\end{array}$ & $\begin{array}{l}\cdots \\
\cdots\end{array}$ & $\begin{array}{l}\cdots \\
\cdots\end{array}$ & & & \\
\hline No. of pat & & . & . & 320 & $106^{*}$ & 505 \\
\hline
\end{tabular}

* One patient aged 50 and a patient using pethidine were not included. 